$\begin{array}{ll} & \text { Etnográfica } \\ \text { etnográfica } & \text { Revista do Centro em Rede de Investigação em }\end{array}$

Antropologia

vol. $24(2) \mid 2020$

Vol. $24(2)$

\title{
No hay vida: desmantelamentos e permanências em bateyes cubanos
}

No hay vida: dismantling and permanence in Cuban bateyes

\section{Carlos Gomes de Castro}

\section{OpenEdition}

\section{Journals}

\section{Edição electrónica}

URL: https://journals.openedition.org/etnografica/8916

DOI: 10.4000/etnografica.8916

ISSN: 2182-2891

\section{Editora}

Centro em Rede de Investigação em Antropologia

\section{Edição impressa}

Data de publição: 1 junho 2020

Paginação: 371-400

ISSN: 0873-6561

\section{Refêrencia eletrónica}

Carlos Gomes de Castro, «No hay vida: desmantelamentos e permanências em bateyes cubanos»,

Etnográfica [Online], vol. 24 (2) | 2020, posto online no dia 31 julho 2020, consultado o 21 janeiro 2022. URL: http://journals.openedition.org/etnografica/8916 ; DOI: https://doi.org/10.4000/etnografica.8916

\section{(c) (i) (8)}

Etnográfica is licensed under a Creative Commons Attribution-NonCommercial 4.0 International License. 


\section{No hay vida: desmantelamentos e permanências em bateyes cubanos}

\section{Carlos Gomes de Castro}

Em 2002, o governo cubano publicou um documento que explicitava a necessidade de "reestruturar" o campo açucareiro. Dezenas de usinas foram, então, desarmadas e desmanteladas, deixando os bateyes sem aquilo que lhes trazia "vida" e "movimento". Neste artigo, intento apresentar como esse processo de "reestruturação" e, ao mesmo tempo, "deterioração" foi percebido, avaliado e ultrapassado pelas pessoas que foram diretamente afetadas por ele. Para tanto, conjugo, numa espécie de descrição por contraste e modulação de escala, as perspectivas do Estado - representada pelos programas de ação e pela construção de uma ideia de "eficiência" e dos moradores de diferentes áreas que viviam da produção de açúcar, para os quais a formulação de temporalidades e o manuseio de materiais aparecem como formas de reajustar um mundo rompido. Do início ao fim, demonstro como o açúcar, ausente, mas presentificado em arruinamentos, é uma substância de longa duração que produz paisagens e altera subjetividades.

PALAVRAS-CHAVE: arruinamentos, espaços afetivos, batey açucareiro, Cuba.

No hay vida: dismantling and permanence in Cuban bateyes - In 2002 Cuban government published a document that made explicit the need to "restructure" the sugar field. Dozens of mills were then disarmed and dismantled, leaving the bateyes without what brought "life" and gave "movement" to them. In this article, I intend to show how this process of both "restructuring" and "deterioration" was perceived, evaluated and surpassed by the people who were directly affected by it. I conjugate, in a kind of description built on contrasts, the perspectives of the State - represented by the programs of action and the construction of an idea of "efficiency" - and those of the inhabitants from different areas that made their living from sugar production, for whom the formulation of temporalities and the manipulation of materials appear as ways of readjusting a broken world. From beginning to end, I indicate how sugar, embodied in ruinations, is a long-lived substance that produces landscapes and modifies subjectivities.

KEYWORDS: ruinations, affective spaces, batey, Cuba.

CASTRO, Carlos Gomes de (cgomesdecastro@gmail.com) - Laboratório de Antropologia de História, programa de pós-gradução em Antropologia Social, Museu Nacional, Universidade Federal do Rio de Janeiro, Brasil. 


\section{INTRODUÇÃO}

iAquí no hay vida! Ouvi essa expressão da boca de várias pessoas, com diferentes entonações, irônicas ou melancólicas, durante minhas investidas etnográficas em Cuba. Muitas são as histórias dela. ${ }^{1}$

Desde princípios dos anos 90, devido à desafortunada conjuntura socioeconômica cubana e aos resultados desastrosos do ramo açucareiro, começou a ocorrer o fechamento seguido de usinas. A palavra de ordem do período era "desmantelar". ${ }^{2} \mathrm{O}$ reinado do açúcar parecia ter findado ou, no mínimo, transferido seu papel para o turismo: "a economia cubana decrescia de maneira tão extensiva quanto havia crescido anteriormente" (Zanetti 2012: 440). Em Matanzas, tal decrescimento tornou-se bastante visível. Assim, em 2012, das 21 usinas que moíam até 2001, apenas três encontravam-se em funcionamento - decadência que se contrastava com o passado de modernização e progresso, descrito por Cantero no clássico Los Ingenios, publicado a partir de meados da década de 1850 (2005: 87, 89). A província matancera deixou de ser área de "notáveis" trapiches, engenhos e centrais, revelando-se como zona de bateyes que experimentavam uma "silenciosa moenda", na expressão de Rodríguez (2013). ${ }^{3}$

Embora seja inegável o declínio da economia açucareira, os resultados negativos não têm como correspondente direto a irrelevância do açúcar como agente. Os dados estatísticos, se observados não somente pela inevitável comparação produtiva, indicam a potencial violência do decréscimo na rotina daqueles que vivem ainda envoltos pelo açúcar. Os números, mais do que quantificar um défice de eficiência, dão sinais da ação do processo de corrosão que altera indústrias e sujeitos que temporizam a vida a partir da relação entre "safra" e "tempo morto" (sem atividade). Dessa perspectiva, sem coroa, o açúcar de cana ainda reina como um problema, mais que isso, afeta, de forma inexorável, a experiência no mundo de muitos matanceros, hoje atrelados à "idade de ouro dos arruinamentos industriais" (Edensor 2005: 5).

I Este artigo é um dos resultados de pesquisa etnográfica realizada entre 2012 e 2016, totalizando 18 meses de campo, divididos em quatro temporadas. Agradeço as considerações analíticas dos pareceristas anônimos. Também saliento a importância dos diálogos com membros do Laboratório de Antropologia e História (PPGAS/MN/UFRJ), em especial Amir Geiger e Olívia Cunha. O projeto recebeu financiamento do CNPq (Processo 140728/2012-0).

2 Convenções: (i) para proteger identidade, os nomes utilizados são fictícios e os bateyes não são especificados; (ii) as aspas duplas são para termos nativos traduzidos e citações diretas de documentos ou livros/artigos; (iii) os itálicos são usados em termos nativos em espanhol e palavras estrangeiras; (iv) as traduções de citações em língua estrangeira são todas minhas.

3 De maneira geral, um batey açucareiro se refere às áreas mais próximas de uma usina, nas quais estariam tanto o edifício da indústria e seus escritórios quanto casas de trabalhadores e comércios. Ortiz (1963 [1940]: 81), a partir de documentos do século xIx, define o batey colonial como espaço que ocupa a função de "centro urbano". Não problematizo esse conceito aqui, que, atualmente, apresenta diversas transformações e nuances. Para análise dessa noção, ver Castro (2017: 53-58). 
O objetivo deste artigo é descrever, a partir das percepções nativas, como o processo de reestruturação da indústria açucareira foi avaliado e conformado pelas pessoas que foram e são afetadas por ele. Além de precisar, por meio de artefatos documentais (Cunha 2010; Castro 2014), como a noção de "eficiência" foi criativamente manuseada pelo Estado cubano ao longo da crise econômica dos anos $90,{ }^{4}$ com vistas não apenas à melhoria produtiva, mas também à formação de sujeitos revolucionários "eficientes" e "inovadores", analiso a recepção da Tarea Álvaro Reynoso, documento governamental que expunha, em 2002, os planos para reverter o dito estado caótico da agroindústria açucareira. Como antigos trabalhadores diziam-me, após a efetuação da Tarea, só restaram as chaminés, que, como grandes obeliscos, materializavam a junção entre um antes dinâmico e um ahora em que o passado prolifera como sucata, aumentando distâncias e produzindo "zonas de silêncio" (Frederik 2012). Fundado nas considerações dos próprios moradores dos bateyes e em consonância com desenvolvimentos teóricos de Navaro-Yashin (2007, 2012), Stoler (2013) e Collins (2013), não detenho a análise numa ideia de arruinamento que estanca a dinâmica da vida, como se produzisse, em função dos desgastes, vazios sociais amorfos - a corrosão pode produzir outras coisas, mesmo provocando tristezas e desânimos. As cartografias de ruínas industriais feitas por Edensor (2005) também me servem de aporte, especificamente a desconstrução empreendida em torno das negativas representações políticas dos arruinamentos, quase sempre tidos como espaços de desordem e de proliferação de resíduos sem nenhum valor. Nessa direção, abordo maneiras de fazer do "desmantelamento" dos centrais matérias que mantêm o movimento e reabilitam "necessidades" (Holbraad 2010) ou, se se quiser, reajustam uma "temporalidade atrofiada" que encerra os sujeitos num limbo de periodicidade indefinida (Navaro-Yashin 2012: 7). Sinalizo que aportes teóricos externos são postos no texto em pequenas doses, pois priorizo as descrições e caracterizações levantadas pelos interlocutores de pesquisa.

Aproximar o olhar desse espaço-tempo do açúcar possibilita compreender, etnograficamente, as ansiedades, espacialidades e temporalidades que estão em jogo nas experiências pessoais de falência das usinas e, em consequência, dos bateyes. Como ficará evidente, o roteiro descritivo e analítico aqui criado modula a escala para obter imagens distintas (mas igualmente complexas) do tema das ruínas açucareiras em Cuba. A modulação se dá entre fatos históricos e políticos mais amplos e eventos corriqueiros (e críticos) de diversas práticas da vida cotidiana: um entre que, às vezes, se transforma em mescla, isto

4 Esse momento ficou conhecido como período especial, nomenclatura eufemística usada para designar as incertezas advindas do colapso do bloco socialista europeu, com o qual a Ilha mantinha estreitas relações. Hernandez-Reguant (2009) e Cunha (2010) não o compreendem simplesmente como periodização cronológica, mas como tempo crítico que produziu transformações subjetivas e sociais. 
porque, em seus relatos, as pessoas misturam, com ressignificações e reapropriações, macro e microeventos para explicitar as marcas tangíveis de passados, conflitos e negociações nelas deixadas. É com um elemento de apreciação e conjunção histórica específica que inicio o exame da "reestruturação" ou "desmantelamento" dos centrais.

\section{DETRITOS DE UM FURACÃO}

O batey onde realizei a maior parte do trabalho de campo possuía, encravada no seu centro, uma indústria açucareira, que dinamizava a economia local e, por extensão, ditava a organização do tempo, vinculada ao ritmo da presença e ausência de rotinas açucareiras: a "safra" e o "tempo morto", denominado de "período de reparação" a partir da revolução cubana de 1959, em alusão à recuperação dos equipamentos usados na produção. Ainda que a expressão "período de reparação" fosse empregada pelos meios de divulgação do governo e diretores da usina, nas falas da população prevalecia a designação "tempo morto", demonstrando que, menos do que um problema de manutenção, estava em jogo a vida do batey mantida pelo andamento do central: não era este que morria, mas sim aquele.

A menção inicial ao "tempo morto" não é desinteressada. Soube já nos primeiros dias de pesquisa que o batey estava distante do competitivo circuito de safras, acompanhado com frequência pela mídia do governo. Tudo ali, como exclamavam, estava "parado", "sem vida". A velha e enferrujada estrutura de ferro do central estava, como num esqueleto, exposta, o que conferia uma atmosfera de decrepitude. As torres (chaminés) encontravam-se frias, não emitiam nenhum sinal que lembrasse os dias de intensa atividade nas caldeiras, quando exalavam grandes nuvens de fumaça - lembrança resguardada, como patrimônio açucareiro, em fotografias de um pequeno museu local. Pelas ruas empoeiradas e estradas de terra mais próximas, havia pedaços de peças já inutilizadas, parafusos, tanques e trilhos de trem carcomidos.

Ao observar esse cenário de desajuste, sucateamento, morte, era inevitável não pressupor que por ali passara algum recente vendaval. E era ao evento furacão Michelle que voltavam para fazer apreciações sobre aquela estampa de arruinamento. O ciclone destruiu, em 2001, várias casas do batey, mas as mais afetadas foram as de madeira, edificadas nos tempos da administração americana com o objetivo de abrigar funcionários brancos importantes. Sem receber reformas adequadas, a maioria dessas moradias arrinou-se. Para moradores do batey, el Michelle, como identificam o tufão entre si, apenas antecipou o desabamento - destino difícil de ser alterado, pois, para renová-las, precisava-se de materiais de construção já quase não disponibilizados nas tendas estatais e caros na bolsa (mercado ilegal). Diante dessa complicada situação, o furacão também foi visto como solução para os problemas habitacionais daqueles que 


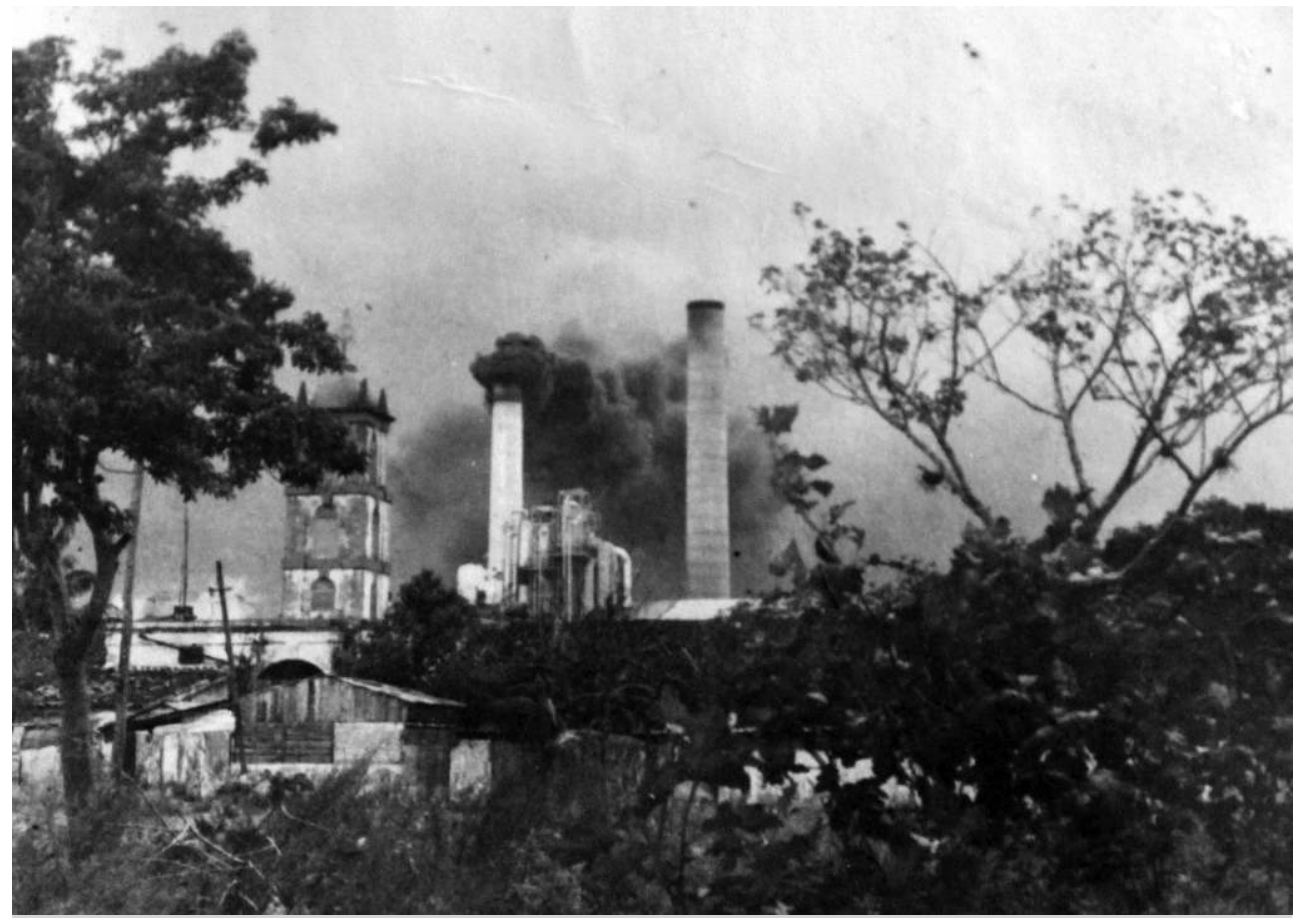

Figura 1 - Espectros de safras.

Fonte: Fotografia de álbum particular de uma moradora, cópia concedida ao autor em 2012.

souberam aproveitá-lo. Segundo uma interlocutora, houve comentários de que, para conseguirem uma casa de alvenaria via auxílios do Estado, isto é, sem gastos particulares, os proprietários mais espertos (até mesmo árduos defensores da revolução) chegaram a derrubar as antigas estruturas de madeira, jurando que os prejuízos vieram da incontrolável ventania.

O furacão também matou animais domésticos, criados para venda e, em menor medida, autoconsumo. Era uma época, como me descreveram, dura; para aumentar a renda familiar, alguns jovens aproveitavam transportes do central e dirigiam-se para polos urbanos para comercializar frangos. Sabiam que as pessoas estavam dispostas a desembolsar valores elevados em alimentos de difícil acesso. Uma ex-vendedora descreveu-me, com minúcia e comicidade, como funcionava esse "negócio":

"[...] Juana começou a vender frango. Eu lhe disse: 'Temos de 'buscar' os fundos para comprar os frangos'. Possuía um par de brincos de ouro, e os vendi... os vendi por 5 dólares. [...] Era um presente da minha tinha Felicia, e eu os peguei para começar a vender frango. [...] saíamos daqui de manhã. Às vezes, tomávamos um carro ali no enfriadero. [...] Comprávamos o frango 
aqui mesmo. Às vezes não encontrávamos frango por aqui, então, íamos a outros bairros. Já voltávamos com a mercadoria, só tínhamos de matar o frango em casa. [...] Quando retornava com ele, meu avô colocava água para ferver e, em seguida, cortava o pescoço do animal assim para retirar o sangue, limpava-o e o abria por completo... e depois só precisava colocá-lo para congelar. $\mathrm{O}$ enchíamos de água com uma seringa para que as coxas ficassem gordas. [...] O peito ficava assim, como lhe dizer, parecido com o de um frango canadense. [...] o colocávamos em um congelador assim, abertinho assim, aí, para que congelasse cheio de água. Era um frango selvagem de seis libras mais ou menos. Nós atuávamos como enfermeiras! Enfiávamos muita água no bicho. Eu falava com a Juana: 'Injete ali!'. E Juana, tchi, tchi, tchi [imitava o som de uma injeção]. 'Juana, vá devagar... assim você vai estourar o frango'. E enche de água, e enche de água. E o animal acabava ficando assim [imitava algo inchado]. [...] [Outras pessoas do batey também costumavam ir para Cárdenas? - pergunto] Juanito, a mulher do Juanito, Esther, a madrinha de Yunay, minha comadre. [...] Juana e eu sempre fomos muito para frente, fizemos amizade com um trabalhador do minguino, um trenzinho. Então, chegávamos, todo mundo subia, e nós íamos até onde ele estava... ia muita gente daqui pra lá: Claudia, Carmen, para que seguir contando! Alina, a filha de Rosa [que mora na Itália], vendeu muito frango em Cárdenas. [...] [Mas vocês só vendiam frango? - indago.] Vendíamos frango, vagem, goiabada. O dinheiro do frango era em dolares, e as outras mercadorias eram negociadas em dinheiro cubano para que a gente pudesse fazer um dinheirinho para comprar algumas coisinhas. E Juana e eu viramos amiguinhas do condutor, do que dirigia, não, do que ficava do lado dele para cobrar o dinheiro do minguino. E então chegávamos e ele pegava nossa sacola... éramos sempre as últimas a montar no minguino... e ele colocava nossa sacola debaixo de um assento. Se aparecesse a polícia, ela já sabia que todo mundo ia no minguino... ninguém que estava no minguino ia passear em Cárdenas, todo mundo ia para vender. Era um transporte de trabalhadores [dizia, aos risos, numa alusão irônica aos ônibus de operários açucareiros das empresas estatais, aqui ocupados para usos extraoficiais ou indevidos]. Assim, quando a polícia aparecia, só estávamos com uma bolsa de guardar dinheiro. Sempre íamos bem arrumadas. A polícia abordava muita gente, se pegasse algo, era preciso pagar mil e tantos pesos de multa e também recolhia as sacolas com os frangos, por maldade. [...] Nunca nos pegaram. Apenas uma vez acharam uma sacola com pimentões que era minha. [Teve de pagar uma multa, então? - interfiro.] Não, porque eu tinha ocultado a sacola em outro lugar. Fiz como se a sacola não fosse minha, que alguém a perdeu ali... pimentões que ainda precisava pagar, pois tinha comprado fiado na mão do Pacheco. Tinha comprado mais de 70 pesos de pimentão. E não paguei nada. Eu disse ao Pacheco: 'Olha, não tenho dinheiro agora'. 
[A verdade] é que comi tudo o que tinha porque depois não fui mais a la lucha". 5

Juana não foi mais para la lucha ${ }^{6}$ - nesse caso, vender frango por la calle sem permissão legal - tanto porque o "negócio" já estava em processo de decaimento quanto porque el Michelle o prejudicou, aspecto destacado por meus amigos em suas falas. Os transtornos surgidos em consequência do ciclone não pararam por aí. O batey ficou sem corrente elétrica por aproximadamente um mês, ao contrário do pueblo (centro da cidade), onde a distribuição de energia foi estabilizada em pouco tempo. Em meio à alta temperatura, novas "lutas" para obter aquilo que não podia ser armazenado de modo adequado foram empreendidas. Era uma "luta" porque a comida, ao lado de mercadorias industrializadas, era escassa. Apesar de a região ser designada como campo - lugar de agricultura e guajiros (caipiras) -, naquele período, não existiam nela tantos campesinos particulares, havia, sim, mais trabajadores azucareros (operários da usina), sem contar que as fincas (sítios) se destinavam à plantação de cana-de-açúcar e não ao cultivo variado, essencial para o abastecimento local. No pueblo, provavelmente, a dificuldade para conseguir a comida diária era maior - isso não quer dizer que no campo tudo estivesse resolvido, como se ali a vida fosse amena. Por exemplo, para manter o consumo estável de arroz - principal cereal da dieta cubana -, muitos passaram a semeá-lo nas valas da rodovia que ligava o campo ao pueblo, a única rota de pessoas, produtos agrícolas e mercadorias industrializadas. Fazendo isso, não ficavam, por completo, reféns daqueles que comercializavam comida por la izquierda (outra nomenclatura para mercado ilegal) a preços exorbitantes.

Por fim, como me contaram, o vento arrancou grande parte da cobertura do edifício do central. Sem eletricidade e com a carcaça exposta, houve atrasos e perdas na produção, que, nos anos anteriores, já entrara numa curva descendente. Colheitas de cana foram igualmente devastadas. Tudo piorou após o incidente; abriu-se margem para a concretização daquilo que era, da perspectiva dos que seriam mais afetados, apenas uma possibilidade: a paralisação das safras por tempo indefinido. Entrava-se, então, em um momento de suspensão da normalidade, quando a expectativa da retomada dos trabalhos passou a habitar o cotidiano do batey. Conjecturavam que, se o furacão não tivesse

5 Em Cuba, há duas moedas oficiais - pesos/moneda nacional (PUC) e pesos convertibles (CUC). Este último surgiu em 2004 como uma forma de retirar o dólar americano de circulação, sendo, primeiramente, utilizado no setor de serviços direcionados a turistas. Para um detalhamento do processo, ver Gordy (2004).

6 La lucha é uma noção bem trabalhada pelos antropólogos que estudam Cuba. Pertierra (2011) analisa diacronicamente esse conceito nativo, demonstrando sua ligação com a flexibilidade das pessoas em criticar e adotar, segundo demandas e estratégias, o socialismo cubano - algo que aparece nas ironias do trecho transcrito. Cf. também Roland (2010). 
provocado aquele tremendo desgaste, a usina não teria sido posta na lista das que seriam desativadas. A explicação do evento normalmente não recaía nos baixos índices de produtividade, pouco compreendidos pelos moradores/trabalhadores, os quais, apoiados em um histórico de sucesso por eles construído, insistiam que ali "se moía bem" e que o açúcar era buenísimo, um dos melhores da ilha, não fazendo sentido a resolução da paralisação. Para eles, só podia haver um equívoco na análise dos economistas.

Se, por um lado, as pessoas não me informavam uma data pontual para a "paralisação" do central, passando por construções temporais diversas - "não faz muito tempo", "há vários anos", "não sei te dizer ao certo, mas...", "está fechado há umas tantas safras" -, por outro, davam-me descrições detalhadas dos vestígios que provocaram alterações e cicatrizes singulares no dia a dia. Seria enganoso afirmar a existência de um completo desconhecimento das consideráveis perdas que o mundo açucareiro cubano apresentava, assim como das medidas adotadas pelo governo para superar a crise. O fato é que a associação do encerramento das atividades da indústria ao furacão Michelle demonstra como a vida ordinária, com seus trâmites, movimentações e transformações, é fundamental na constituição de periodizações, que não são demarcadas ou rememoradas por elementos avessos à experiência pessoal, mas por aquilo que faz marcas subjetivas tangíveis (Navaro-Yashin 2007). A cronologia, como notação exata de uma série de acontecimentos, fica em suspenso. Dessa forma, pouco importa o ano que determina, taxativamente, quando o central foi fechado. Sozinho, o grupo de números formaria uma temporalidade estanque e vazia, sem pertencimento às vidas que a constituem. Ela se torna presente somente quando preenchida com pontos de vista, objetos e expressões dos que a experimentam.

\section{UMA CARGA INSUPORTÁVEL, DO PONTO DE VISTA DO ESTADO}

O "reordenamento" foi amplamente divulgado pelo jornal Granma. Em 20 de dezembro de 2002, Juan Varela Pérez - jornalista da imprensa oficial que acompanhava o transcorrer da economia açucareira - resumia as discussões estabelecidas entre deputados da Asamblea Nacional del Poder Popular, oferecendo ao leitor "informações das transformações" e "valorações" sobre o andamento inicial da Tarea Álvaro Reynoso. O texto pretendia "aclarar inquietações a respeito dos serviços que as entidades açucareiras brinda[va]m às comunidades e aos bateyes". A população temia que, com a desativação dos centrais, também fosse desestruturado tudo o que a eles se ligava. A preocupação não era sem razão, dado o quadro de completa dependência de algumas áreas industriais e agrícolas. O então deputado Carlos Lage, vice-presidente do Conselho de Estado e um dos proponentes da reforma, chegou a pontuar que, após "uma detalhada revisão de central por central, serviço por serviço, $[\ldots]$ comprovou-se 
que em algumas zonas até as funerárias eram do Ministério do Açúcar”. A "reestruturação", segundo os políticos e investigadores que a promoviam, não permitiria retrocessos nos serviços prestados nem deixaria os trabalhadores desamparados. Ao contrário, ela objetivava uma "eficiência" que traria melhorias não apenas aos locais que permaneceriam no fluxo produtivo das safras anuais, mas também aos engenhos que se encontravam com graves "problemas acumulados" e que, por isso, seriam "paralisados". O discurso de Lage ressaltava apenas o caráter "positivo" do processo, não jogava luz em possíveis falhas e incompatibilidades com o projeto revolucionário. E se a Tarea não funcionasse? As considerações do político se baseavam no Documento Programático publicado em maio do mesmo ano pelo extinto Ministério do Açúcar, ${ }^{7}$ no qual se defendia a ideia de que "não ha[via] outra alternativa senão pôr em prática [um programa de] profundas mudanças", qualificado, em outro material governamental, como uma "verdadeira revolução". 8

A dimensão do sistema agroindustrial açucareiro cubano - com 154 centrais no período - tinha se tornado, segundo o ministério, defasada, incoerente com a situação financeira do país, uma "carga insuportável". Para revigorar aquilo que atuara como sustentáculo da economia, seriam necessários câmbios nos parâmetros organizacionais e na "mentalidade dos dirigentes e produtores, [de modo que o] gerir economicamente se converte[sse] no principal método de trabalho" (Minaz, 8 de maio de 2002, cit. em Rodríguez 2013: 41). A estratégia buscava justificativas inclusive nas primeiras apreciações de Fidel Castro sobre a problemática açucareira, mostrando que, desde a infância do triunfo da revolução, já se observava a necessidade de um remodelamento nessa área produtiva, ação protelada em função dos lucrativos intercâmbios estabelecidos com o Leste Europeu. Em matéria de 24 de outubro de 2002, por exemplo, para concluir suas análises dos "logros" que estavam em curso, Juan Varela Pérez citou o seguinte trecho de discurso proferido pelo comandante em 1960:

“[...] Se fosse possível começar a organizar de novo toda a produção açucareira, o que faríamos em primeiro lugar seria buscar as melhores terras para esses cultivos, planejar uma agricultura diversificada e calcular quantos centrais seriam necessários para produzir determinada quantidade de açúcar". 9

7 Extinto em 28 de outubro de 2011 , pelo Decreto-Lei n. ${ }^{\circ}$ 287. Em 10 de novembro, criou-se a Organização Superior de Direção denominada Grupo Açucareiro, AZCUBA (Decreto n. ${ }^{\circ}$ 294).

8 Minaz: "Síntesis de algunos argumentos imprescindibles para los cuadros que en las provincias van a conducir el proceso de reuniones informativas", 8 de maio de 2002. Cf. Rodríguez (2013: 39-41).

9 Ver artigo de Juan Varela Pérez, "Agroindustria azucarera: La reestructuración es el camino adecuado", Granma, 24 de outubro de 2002 (disponível em < http://www.granma.cu/granmad/2002/10/24/ nacional/articulol 5.html >, última consulta em junho de 2020). 
O documento do ministério não permitia questionamentos acerca da irrevogável reestruturação; entretanto, não deixava claro o que de fato significava a interconexão entre "mentalidade" ("reestruturada" e "transformada") e "gerir economicamente". Nas entrelinhas, dava a entender que estava em pauta a ideia de educação para a "eficiência".

\section{APRENDENDO A EFICIÊNCIA}

O governo cubano já discutia ajustes que seriam postos em prática para sincronizar a produção de açúcar com as reais possibilidades do país há mais de uma década. Os tópicos abordados eram dos mais variados, considerando a complexidade e extensão desse tipo de indústria. Em junho de 1991, uma das preocupações era como diminuir perdas com as "reparações de safra". Até então, quando terminavam suas atividades, os centrais "paravam" entre abril e maio para que fosse feito o "desarme" e o "alistamento" dos moinhos e demais instrumentos; apenas por volta de agosto é que começavam as reparações em massa, deixando todo o aparato do engenho limpo e preparado para ser utilizado na safra seguinte. No processo, peças e materiais diversos eram inevitavelmente perdidos e danificados, o que aumentava os custos de manutenção e prejudicava o andamento e a organização dos trabalhos futuros. Se, anteriormente, isso já era uma questão debatida, com a efervescência do período especial tudo apenas se complicou: a fabricação e a compra de instrumentos deteriorados, extraviados ou inutilizados foram dificultadas e até impossibilitadas. Com o objetivo de ultrapassar esses empecilhos, o ministro Juan Herrera recomendava que o desarme se realizasse somente em casos extremos, uma vez que a maioria dos equipamentos não precisava de mais do que "revisão, limpeza e conservação". Para ele, a prática de "pôr abaixo o engenho", isto é, desarmá-lo, era "anacrônica e obsoleta". ${ }^{10}$ Os centrais eficientes seriam os que conseguissem modificar esse hábito e exigissem ações inteligentes e precavidas de seu pessoal.

Os verbos reutilizar, recuperar, assegurar, aproveitar, manter, proteger e economizar descreviam parte das atitudes de trabalhadores "capazes e experimentados" - aqueles que não permitiam retrocessos na produção devido à menor quantidade de recurso disponível e ausência quase total de importação, impossibilitada, como sempre lembrava o governo, pelo embargo norte-americano. Em muitas manchetes e legendas de fotografias, a Bohemia apresentava tal tipo de operário como modelo de "inovação", "eficiência" e "sagacidade": "Os imprescindíveis são os que criam com seu próprio esforço, sem basear o

10 As expressões e palavras do parágrafo que estão grafadas entre aspas estão presentes no artigo de Juan Varela Pérez, "En condiciones de período especial: nuevo concepto en las reparaciones de zafra", Granma, 1. ${ }^{\circ}$ de junho de 1991, p. 4. 
trabalho, como faziam os antigos alquimistas, na arte quimérica da transformação dos metais"; "A vontade não tem limites: jovem com seu trabalho silencioso evita importações ao país"; "Utilizam poucos recursos e muita pujança e iniciativa - não são extraordinários, mas sim homens decididos a solucionar". ${ }^{11}$ Alguém com "conduta revolucionária" deveria basear-se nesses exemplos de corajosa "iniciativa", não na "valentia" de um "antissocial qualquer" que se "confund[ia] com a propaganda inimiga", isto é, capitalista e individualista, como endossava o colunista Luís Sexto, defensor ortodoxo da revolução. ${ }^{12}$

A preocupação com o ahorro (poupança), conquanto sempre tangenciasse o mundo do trabalho, na medida em que cada cidadão era visto como potencial trabalhador, não se restringia a ele nem à agroindústria açucareira. Atravessava diferenciados âmbitos, abarcando gerações variadas, como se todos - desde aqueles que operavam na limpeza da cana a ser moída em centrais e mulheres que reciclavam sapatos e reaproveitavam alimentos na cozinha, até coletores de caixas de papel e crianças criativas e econômicas - tivessem algo para aportar à eficiência que protegeria os cubanos e as empresas estatais, em suma, o país. Tentava-se educar para o ahorro, e os meios de comunicação, via campanhas publicitárias, contribuíam para que isso fosse realizado.

Circularam, na época, diferentes propagandas e projetos educativos sobre o tema, normalmente com imagens divertidas e didáticas. ${ }^{13}$ Com essa intenção, a Bohemia veiculou, nos primeiros meses de 1990, a chamada para um concurso de creación infantil direcionado a alunos da primaria - os pioneros (crianças da educação infantil e ensino fundamental) -, cujo tema era nada menos que ahorro de energia elétrica - uma clara ligação com os apagões do período especial. Mesmo que especificasse aquilo que não deveria ser desperdiçado, a convocação ensinava, de antemão, que ahorrar era crescer, pouco importando o que fosse poupado. Como ilustração, havia um boneco que segurava uma tocha triangular - emblema dos pioneros de José Martí - e usava um capacete de operário, como se afirmasse que cada estudante podia assumir a postura de um eficiente trabalhador revolucionário. ${ }^{14}$ Se quisessem ser como el Che, como dizia parte do lema que repetiam nos dias de festa ou perante a bandeira hasteada, precisariam abraçar essa atitude, só assim "cumpririam” com a revolução e com

11 As menções referem-se, respectivamente, às seguintes edições da Bohemia em 1990: 16 de fevereiro, p. 26; 2 de março, p. 27; 15 de junho, p. 48.

12 Para publicidades de teor educativo, ver Bohemia, 24 de abril de 1992, p. 31.

13 Ver Bohemia, edições de 28 de setembro de 1990, p. 19; 13 de dezembro de 1991, p. 59; 18 de junho de 1993, p. 67.

14 Segundo o Portal Educativo Cubano, o emblema é "composto de dois triângulos, um vermelho e outro azul. O triângulo vermelho representa o sangue derramado na luta por liberdade, em seu centro destaca-se a estrela solitária, como expressão de que Cuba é um país livre e soberano. O azul representa o céu da Pátria. Os vértices do triângulo significam estudar, trabalhar e lutar pela pátria socialista" (encontrado em $<$ http://educaciones.cubaeduca.cu/index.php?option $=$ com_content\&view $=$ article\&i$\mathrm{d}=367$ \& Itemid $=4>$, já não disponível, última consulta em dezembro de 2016). 
os desígnios guevaristas. ${ }^{15}$ Sem exagero, o ahorro surgia como uma nova arma de "combate" dos e para os jovens "guerrilheiros". Não obstante, eles tinham de aprender a manuseá-la. O exemplo dos adultos aparecia como algo essencial nessa tarefa, seja para poupar pesos, seja para conservar e reutilizar mercadorias: iTengo diez años y ahorro como papá!, exclamava um garotinho, sozinho na fila de um caixa bancário, numa publicidade do Banco Popular de Ahorro. ${ }^{16}$

Os pioneros também figuravam na Bohemia como "inovadores". Importantes atores na batalha pela eficiência, eles, mais do que educados para um projeto futuro, distante, eram impulsionados a agir no agora mais imediato, a fim de que servissem de referência de "iniciativa" para seus "companheiros". O breve relato de Yésell Candelario Benítez, publicado em junho de 1992, acentuava esse aspecto. Com apenas sete anos de idade, mas comportando-se como alguém mais velho, esse garoto de Ciego de Ávila, estimulado por seus pais, inscreveu-se no Forum Nacional de Piezas de Repuesto, Equipos y Tecnología de Avanzada para divulgar sua "inovação": convertera puxadores de latas de carne, comumente descartados, em sovelas, agulhas de costura, chaves de fenda e anzóis. Ele justificava seu interesse em reaproveitar materiais como uma forma de revelar-se, na prática, como "um menino revolucionário" que produzia "algo útil ao país". ${ }^{17}$

Acompanhando a junção desses posicionamentos e histórias na revista, verifica-se a moralidade que sustentava a ideia de eficiência, a qual se vinculava altamente à concepção de trabalhador (homem, mulher, criança ou idoso) "econômico", "inovador" e "iniciativo" - alguém que não pensava no que seria exclusivamente do indivíduo (no "seu"), mas no "nosso", estando, por isso, sempre disposto a entregar-se com "fidelidade" à labuta e ao "aperfeiçoamento integral" do projeto socialista. ${ }^{18}$ Como afirmava certo mecânico: "Os equipamentos só morrem quando morre o homem". E, desvinculando seus interesses do desejo de maiores retornos financeiros, complementava: "Juan e eu ganhamos 256 pesos mensais, não recebemos hora extra [...]. Acreditamos nos estímulos morais". ${ }^{19}$ Ser visto como um "inovador" que "dava tudo de si mesmo" para que o país progredisse, mesmo com pouco e sem a necessidade de recorrer a investimentos em divisas, era signo de distinção. Produção e moral caminhavam, portanto, lado a lado, numa relação que transformava a eficiência não apenas em índice a ser calculado, mas em dever a ser incorporado e transmitido - daí o caráter pedagógico das publicidades e notícias propagadas

15 Lema completo: Pioneros por el comunismo, iSeremos como el Che!

16 Ver Bohemia, 16 de fevereiro de 1990, p. 35.

17 Ver Bohemia, 12 de junho de 1992, p. 24.

18 Em 1994, o colunista Nestor Núñez dizia: "[...] a eficiência tem de abrir fronteiras e converter-se em um legítimo sinônimo de perfeição integral de nosso projeto" (Bohemia, 18 de março de 1994, p. 37).

19 Ver Bohemia, 16 de fevereiro de 1990, pp. 27-28. 
pela imprensa, sintetizado nesta colocação de María de los Ángeles Rodrígues, jornalista que entrevistava aqueles que se destacavam pela disposição em recuperar sucatas e ahorrar: "Nosso propósito é oferecer aos leitores" - também inseridos nesse extenso processo de recuperação e criação de nova mentalidade "[...] uma amostra de informações para destacar a importância que eles [os 'inovadores'] dão ao dinheiro produzido pelo povo". ${ }^{20}$

\section{EM NOME DA REVOLUÇÃO}

Além de esquadrinhar os sentidos do conceito de eficiência, os pontos discutidos até aqui demonstram que, dada a preponderância da escassez de recursos, desativações foram conduzidas em diferentes localidades e ramos industriais, no intuito de que a "máxima produtividade com baixo custo" fosse alcançada. Contudo, a Tarea Álvaro Reynoso foi um projeto marcante: tratava-se de uma proposta de transformação do setor que mais oferecia histórias e qualidades à ilha. Se em décadas anteriores a agroindústria açucareira fora foco de intensa atenção em razão de seus benefícios econômicos e dos investimentos e ampliações nela feitos, como no caso da controversa zafra de los 10 millones ${ }^{21}$ na entrada do século XXI, ela tornou-se tema de debate por sua desfiguração e prováveis interrupções. Se em 1969 a preocupação era educar jovens zafreros (outra forma de indicar os trabalhadores açucareiros), incluindo estudantes da secundária (anos finais do ensino fundamental), no controle do processo de fabricação do açúcar e no "idioma da safra", uma vez que, como o governo revolucionário repetia, todos precisavam saber os sentidos dos métodos e palavras que configuravam a empreitada que retiraria o país do subdesenvolvimento, ${ }^{22}$ em 2002, o discurso se deslocou da área interna do central para os escritórios de recursos humanos e levantamentos econômicos, dando vazão à necessidade de convencimento acerca da premência de cortes, realocações, atualizações - tudo interligado à ideia de "reestruturação" como "eficiência". Enquanto em um dos tempos a indústria açucareira parecia expandir-se de forma ilimitada, sem qualquer previsão de falência ou inadequação, no outro, o encurtamento passava a prevalecer, com espaço de atuação apenas aos "eficientes", aos que "trabalhassem de verdade", como falava um engenheiro que acompanhou a Tarea (Rodríguez 2013: 81).

20 Ver Bohemia, 16 de fevereiro de 1990, p. 29.

21 A zafra de los 10 millones, 1969-1970, mobilizou todo o país numa "marcha" para bater a meta jamais alcançada em qualquer safra açucareira. A revista Bohemia acompanhou-a. Meses antes do término, era perceptível que não seria possível atingir o montante determinado. Trabalhadores comentam os erros cometidos a obter maiores ganhos no período.

22 Sobre o idioma da safra, cf. Bohemia, 11 de julho de 1969, pp. 32-40, 56. No editorial, sugeria-se, num "plano de férias", que os estudantes visitassem canaviais - tudo com vistas a educar para a safra. 
Apesar dos contrastes, as ações de abertura ou fechamento tinham um elemento em comum: ambas se justificavam na revolução, que, como sujeito, solicitava aos cidadãos cubanos - aglomerados na noção de "povo" - "sacrifício", "apoio" e "confiança" em suas medidas e posicionamentos, às vezes bastante díspares. Assim, no processo de 2002, os documentos destacavam o papel dela desde o dia em que Cuba optou pelo rompimento com os Estados Unidos após a reforma agrária de 1959: "A Revolução não cruzou os braços [diante das investidas norte-americanas contrárias à produção interna]; nacionalizou os centrais açucareiros, tornando-os propriedade de todo o povo" (Minaz, 8 de mayo de 2002, cit. em Rodríguez 2013: 43-53). Eles também atribuíam qualidades a seu caráter: "É uma conduta inalterável da Revolução falar com clareza a nosso povo e tomar as decisões oportunas que cada situação aconselha"; "A Revolução sempre diz a verdade, nunca enganou o povo".

Em nome da revolução (ou sob sua autorização), operou-se, portanto, "a grande transformação do setor açucareiro", e, em pouco tempo, a paisagem dos rincões movidos a açúcar entrou em um implacável processo de corrosão. Dez anos depois, em 2012, quando visitei pela primeira vez um batey, avaliações e reflexões sobre a Tarea e a reestruturação ainda eram feitas. Havia quem concordasse com o que fora estabelecido, especialmente os que se beneficiaram com as medidas administrativas e governamentais, e também aqueles

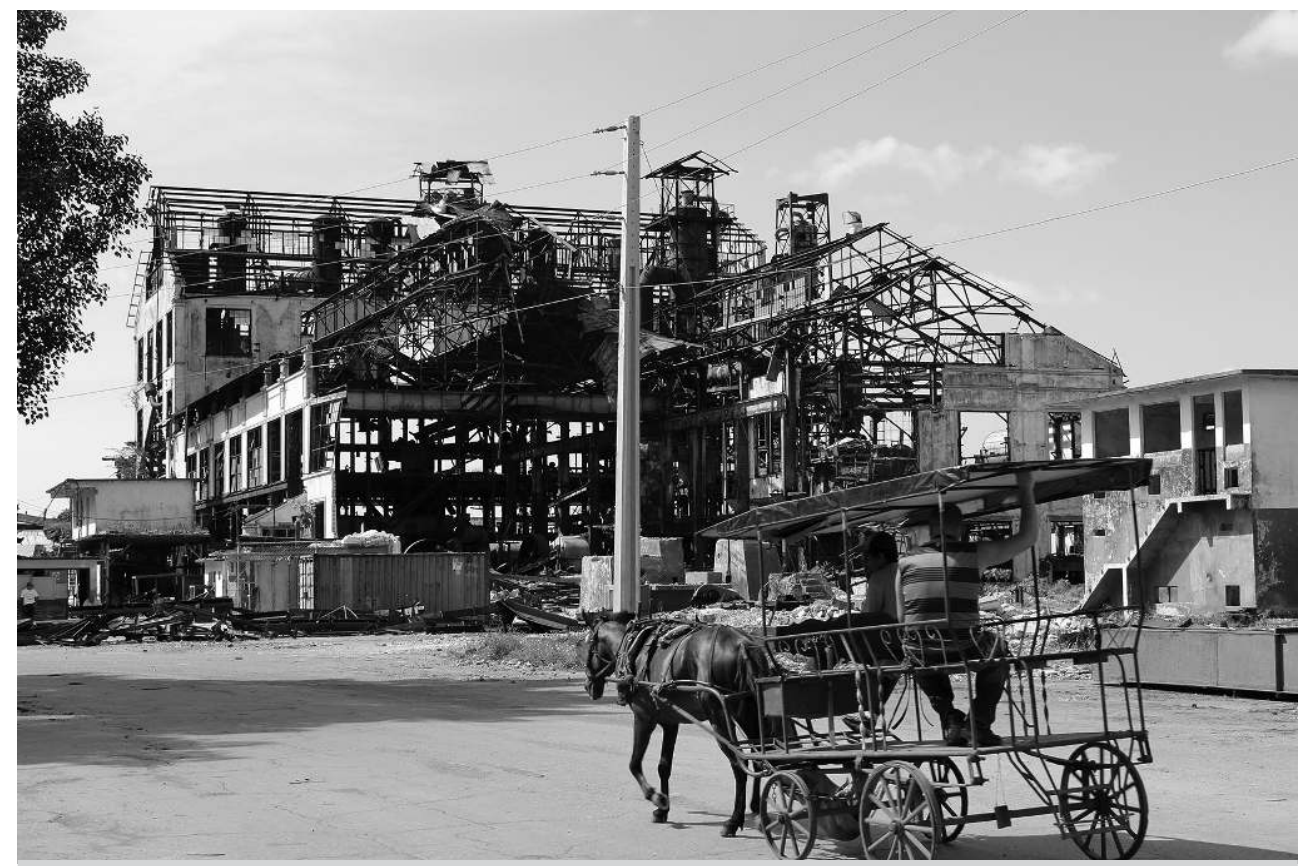

Figura 2 - A imponência do metal: central desmontado.

Fonte: Arquivos do autor (Matanzas, Cuba, 2015). 
que eram críticos ferrenhos, dizendo que nem sequer chegaram a entender o porquê do fechamento da usina local por tantos anos - para eles, os motivos nunca foram claramente explicitados.

Esse encontro inicial deu-me apenas alguns sinais das questões atreladas à desativação das usinas. Foram as viagens a muitos bateyes mantanceros sem central que me ensinaram a observar um mundo em que as chaminés se mantinham como materialização perene de um antes que insistia em povoar um ahora contra o qual as pessoas necessitavam lutar.

\section{ANTES E AHORA:}

\section{PERCEPÇÕES E AFETOS DO DESMANTELAMENTO}

A conversa com Beré aconteceu em frente ao que fora o enfriadero do central desbaratado, ou seja, o local para onde se conduzia, para ser resfriada, a água quente que saía da fábrica. Com o fechamento, as tubulações do enfriadero foram retiradas pela empresa açucareira para que se improvisasse uma piscina. Essa transformação se adequava às tentativas de dar nova função às construções que não fossem totalmente destruídas, tal como ocorria com as salas dos escritórios e com o terreno em que, antes, se erguia toda a estrutura do edifício que abrigava os moinhos e demais maquinários, ambos reutilizados na redistribuição de casas a muitos migrantes que chegavam à parte ocidental de Cuba. Readaptações desse mesmo tipo apareciam em outras localidades, não sendo algo que singularizava aquele batey. Como a "piscina" estava vazia, perguntei a Beré se ela realmente funcionava: "No verão", respondeu. "No entanto, às vezes não podem enchê-la, porque aqui temos problema com água". Expliquei-lhe que a indagação se baseava em experiências semelhantes de outros centrais, onde as "piscinas", em curto período, foram abandonadas e completamente destruídas. Ele também ouvira falar de casos parecidos, e disse que ali isso ocorrera com a horta local, construída em um espaço diante da chaminé do central. Antes, Beré argumentava, plantava-se bem e a distribuição de hortaliças era suficiente para atender às demandas dos habitantes. Ahora, ao contrário, já não se produz quase nada, não "serve para nada". Para o aposentado, nenhuma das readaptações conseguia reaver, com novas formas, o papel do central. Tudo ficava aquém. ${ }^{23}$

Ele avaliava que, com o agravamento da situação do transporte, representado pela constante necessidade de fazer tramos - decompor percursos, prolongando, por horas, viagens curtas - para entrar ou sair daquela área, houve também decréscimos na qualidade de vida e precarização dos comércios estatais locais: "Antes, todos os dias chegava um caminhão com mercadorias para 
a cafeteria do central, caixas de croquete, refrigerante, gordura de porco, de tudo. Ahora, é um senhor que traz uma sacola com pacotes de croquete, ovos, um copinho de gordura [...]. Você acha que isso é suficiente?" O fechamento do central significou, assim, menor quantidade e variedade de alimento disponível. Em outro batey, uma senhora destacou que até o envio de ossos de boi, empregados na preparação de sopas e no cozimento de feijão, foi alterado: nos açougues dos centros urbanos, esses restos podiam ser mais facilmente encontrados, já nas antigas comunidades açucareiras, tornaram-se raros.

Beré não concluiu sua análise conjuntural no tema da comida. Incluiu também aspectos que, ao ultrapassar os limites restritos das paredes e estruturas da usina, atingiam as casas dos arredores, como se houvesse uma imbricação entre os dois mundos - o da indústria e o das habitações familiares, um servindo-se do outro, com o detalhe de que, numa leitura abarcadora da noção proclamada por Fidel de que o "central era do povo", a primeira era uma espécie de extensão do quintal das segundas, quase uma oficina mecânica caseira onde tudo se encontrava gratuitamente disponível. Por exemplo, se ocorresse o rompimento de materiais de ferro de uso doméstico, não havia nenhum empecilho em utilizar ferramentas da empresa nem em buscar um soldador que trabalhasse aí, o qual realizaria o serviço sem cobrar nada, no máximo esperaria o cumprimento de favores não monetários entre "amizades". Com o "rompimento" da usina, as famílias deixaram de gozar dessa relação com as coisas do Estado, passando a ter de frequentar o pátio particular de seu vizinho, onde os objetos tinham proprietários individuais bem demarcados (mesmo aquilo que tinha sido "retirado" de propriedades estatais) e valores em pesos. Ainda era possível encontrar soldadores e mecânicos, mas já não prestavam serviços gratuitos, cobravam por cada peça reconstruída; como nem todos tinham condição de pagar pelos consertos, as casas, como extensões diretas da indústria que se fue abajo (decaiu), também passaram a deteriorar-se. A respeito das "amizades", saliento que meus interlocutores gostavam de reiterar que no passado elas eram "mais sãs", menos interessadas, e que hoje isso tinha cambiado, transformação para a qual contribuíram os variados problemas do período especial e, sobretudo, as dificuldades provenientes da falência da produção açucareira que movia a comunidade. Falavam que a tudo se acrescentou um preço, uma tarifa, desde as frutas, que davam em abundância e, para que não apodrecessem, eram partilhadas, até as amizades, as quais só se mantinham quando davam algum "negócio". ${ }^{24}$

24 O tema da moralidade ganhou relevo nos trechos anteriores. Ele aparece em outras etnografias, estando localizado, normalmente, como uma forte questão advinda do período especial nas falas e observações colhidas por antropólogos. Logo, não é somente um aspecto particular do batey, mas também algo que atinge outras áreas. Os estudos tratam, direta ou indiretamente, de problemas ligados a arruinamentos, materiais ou econômicos, e, claro, a transformações dos regimes de socialidade. Stout (2014: 4) mostra como a intimidade alterou-se com o retorno da circulação do dólar em Cuba, a reabertura para o turismo internacional e os novos mercados, junto das mudanças atreladas ao sexo, família [continua] 


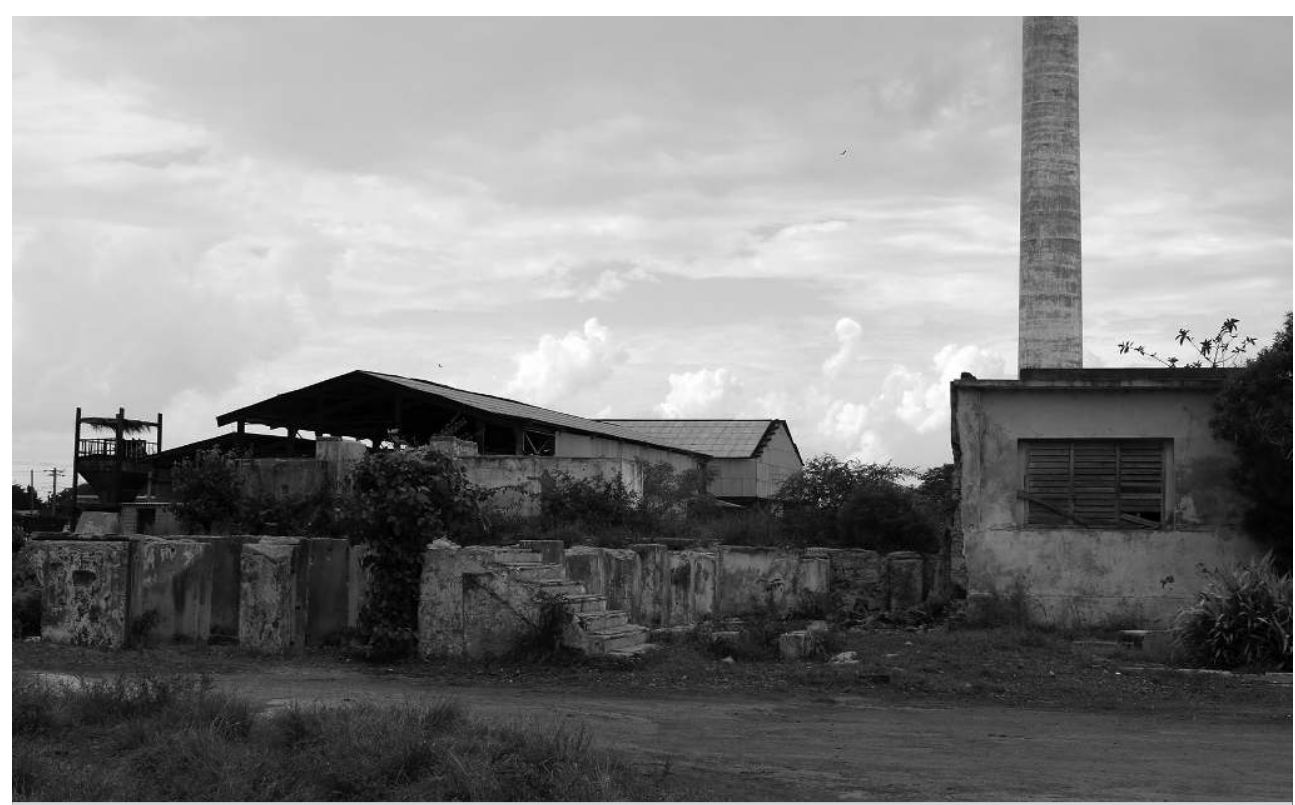

Figura 3 - Zonas de silêncio. Fonte: Arquivos do autor (Matanzas, Cuba, 2016).

Lino media, igualmente, o ahora em função do antes. Por ter-se aposentado cedo, com menos de 50 anos, ele não sofreu diretamente com a decisão do governo de fechar o central. Em seu batey, a "paralisação" ocorreu em 1997: "Havia pouco abastecimento de cana. Mandaram aguantarlo [mantê-lo com as peças], depois, disseram que, quando houvesse recuperação de cana, iriam arrancar la molida outra vez. Mas fizeram o contrário. Mandaram desativá-lo, desbaratá-lo". Suas observações fundamentavam-se em sua longa trajetória como pintor do engenho, que, embora lhe tivessem imposto o selo da ineficiência, "moía que era uma beleza". Não se furtava de lembrar que seguira uma genealogia açucareira, como muitos de seus amigos: "Meu pai trabalhava aí. Meus irmãos também. Quase todos trabalhavam aí. Todos tinham algum posto nesse central". Para ele, antes, dedicar-se à empresa dava reconhecimento ao sujeito - sempre queriam que alguém da família fosse vinculado ao "açúcar" -, além de que o salário não era ruim e havia bonificações e incentivos. Cuidara de suas filhas com o dinheiro do central, mas, quebrando a genealogia, elas optaram por carreiras fora da produção açucareira. Lino elencou cada um

e trabalho. De acordo com a autora, "a intimidade ofereceu um refúgio, um potencial santuário, mas também emergiu como um perigoso terreno no qual novas desigualdades inerentes aos mercados capitalistas puderam diminuir os sentidos da lealdade e reformular o significado de afeto genuíno". Tais alterações, semelhante às exposições acima, eram indicadas e problematizadas pelos interlocutores de Noelle Stout. Cf. também Simoni (2015) e os artigos sobre moralidades e mercados em experiências pós-socialistas na coletânea organizada por Ruth Mandel e Caroline Humphrey (2002). 
desses pontos tendo como referência os anos anteriores a 1990. Queria mostrar-me que, nessa época, o dinheiro valia mais. Aposentara-se com 200 pesos, uma quantia que lhe permitia ir à cidade e "caminhar para todos os lados", algo que sempre gostou. Depois, no entanto, vieram os cambios do período especial e anos seguintes, com o evento não menos complicado de encerramento do engenho, e seus 200 pesos transformaram-se em míseros 8 pesos, ou seja, 8 CUC. ${ }^{25}$ Seu salário já não "alcançava", mas, pela idade, não podia trabajar por otros lados para conseguir alguns pesitos, como seus vizinhos faziam, que buscavam pincha (trabalho) na agricultura, deslocavam-se pa'quí, pa'llá (por muitos lugares) em pequenos "negócios" ou tentavam emprego fixo nos escassos centrais en marcha (ativos).

Como não gostava de estar parado nem da monotonia, Lino evocava um passado em que o batey, sempre dinâmico, recebia profissionais de outras províncias durante as safras. A caracterização se contrastava, em sua opinião, com o presente, quando havia pouca gente circulando pelas ruas empoeiradas e quase sem tráfego de carros: "Hoje isto aqui está assim...", dizia, com descontentamento e tristeza. "Ai, meu Deus! Muito pouco movimento. Não é fácil".

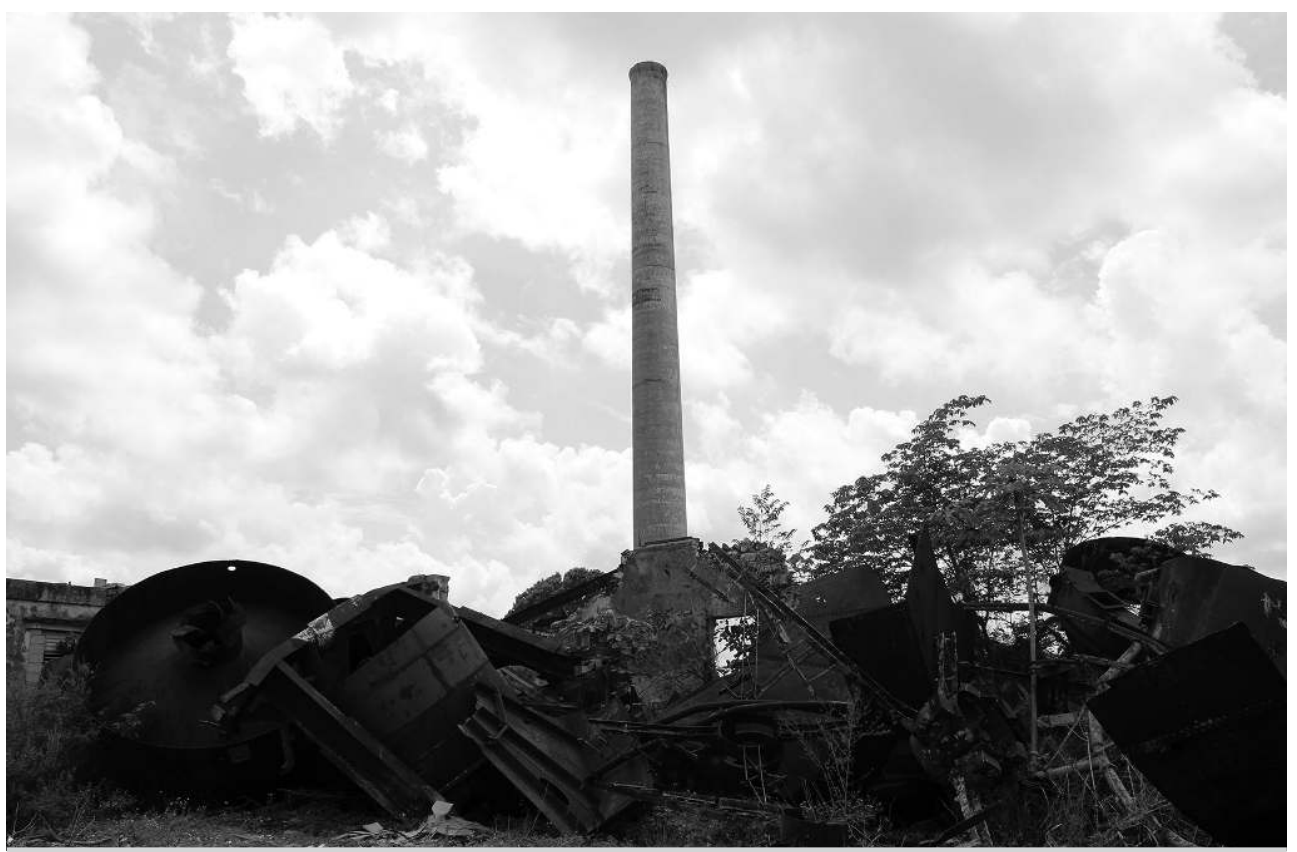

Figura 4 - Idade de ouro do arruinamento. Fonte: Arquivos do autor, Cuba, Matanzas, 2016.

25 Aqui o CUC é referido como pesos, nomenclatura usual no meio rural. A prática é o que define se o que está em questão é um valor em pesos convertibles ou em moneda nacional, normalmente basta saber se se trata de produtos industrializados, mas isso pode variar. Fula, chavito e dólar são outros nomes para o CUC. 
Ele ainda afirmava que lá não era lugar para a juventude, porque inexistiam possibilidades de divertimento. Não era igual aos bateyes que, mesmo na ausência do açúcar como protagonista, beneficiavam-se com o turismo ou com o fácil acesso a rodovias e cidades importantes, como acontecia nos Centrais Austrália e Espanha - o primeiro no caminho para a Ciénaga de Zapata (sítio de turismo campestre) e o segundo numa estrada que conduzia facilmente a Cárdenas e Varadero (local de resorts). A localização de sua comunidade não favorecia entrada nesses circuitos. Desse modo, sem o central, ela também se desmantelou, como se, dia a dia, algo fosse dela retirado (objetos, máquinas, jovens que se mudavam por falta de oportunidade), criando uma constante sensação de vazio e melancolia.

Pautando a análise nos estudos de Navaro-Yashin (2007, 2012) sobre os cipriotas turcos, é possível afirmar - com as devidas diferenciações históricas e etnográficas - que tal sensação não se configurava apenas como sentimento interno ao sujeito (no limite, desconformidade); era algo também "exsudado" pelos próprios objetos e espaços, transfigurados, então, em "espaços afetivos" e detritos ou rastros melancólicos deixados por um central que já não existe como no passado e pelo qual muitas famílias de trabalhadores passaram e mantiveram-se - "cicatrizes na paisagem" (Edensor 2005: 21) que não permitem ser esquecidas e que emanam a memória de uma socialidade perdida. Nas palavras da autora: "Uma paisagem de ruínas descarrega um afeto de melancolia. Ao mesmo tempo, aqueles que habitam esse espaço de ruínas sentem melancolia" (Navaro-Yashin 2012: 172). Recordo-me que, certa tarde, ao voltar de uma feira agrícola, um garoto mencionou a tristeza que havia naquelas bandas. Cruzávamos exatamente as ruas de um batey sem seu central. A paisagem da situação: ruas paradas, silenciosas, algumas paredes quebradas, latarias e, ao redor de tudo, a carcaça da usina. O espaço afetava, produzia melancolia. O rapaz, pela pouca idade, jamais fora um operário, porém, seu pai assumira, antes, a tarefa de caminhoneiro do açúcar, ahora preferia fazer outros "negócios", vendendo, por exemplo, seus serviços a campesinos. Lino também trouxe outra potente comparação entre o antes (dinâmico, produtivo, bonito, cheio de vida...) e o ahora (monótono, difícil, improdutivo, triste...) que ilumina a ideia de espaços afetivos:

"Antes aqui não faltava festa. Ahora tem de ir para Manguito para ver se tocam alguma coisa no Círculo de Trabalhadores [no passado, um lugar de encontros festivos dos operários]. Aqui não tem nada, o que alguém vai fazer aqui? Nem uma vitrola. A vitrola muito boa que havia ali [no Círculo]. [...] A gente colocava un medio [quinze centavos de peso] e saía o disco que a gente quisesse. Ahora tudo isso sumiu. Não somente aqui, mas em Manguito também. Levaram essa vitrola, tudo isso foi levado. Antes havia de tudo, o 
que você quisesse. Eu lhe digo isso porque nasci e fui criado aqui." [O edifício do Círculo permanecia no batey, já as interações nele desenvolvidas, não.]

Imersos nessa geografia e manipulando uma "temporalidade interrompida" (Navaro-Yashin 2012), haja vista a falência de tempo indeterminado, os moradores dos bateyes têm de "lutar" contra o arruinamento. Para tanto, eles religam/movem coisas em busca da transformação do batey. Tudo se passa como se eles estivessem, individual e coletivamente, refazendo o batey, segundo, digamos, uma convivialidade pós-açucareira. Nisso, a "eficiência” pretendida e ensinada pelo Estado, por meio de seus diferentes feixes de atuação - mídia, escolas, Comitês de Defesa da Revolução, reuniões de empresas estatais, documentos, entre outros -, exerce um papel importante, em especial no que tange ao remodelamento das coisas. Todavia, há uma grande diferença entre o imaginado sujeito eficiente e o sujeito que passa a manipular sucatas de usinas: para o primeiro, a eficiência se converte em produção em prol do socialismo revolucionário e suas moralidades; já no segundo, a eficiência se reconfigura em astúcia, entendida aqui como modo de ajustar a vida individual e da comunidade a partir daquilo que se desangra (retira) do Estado, sem que haja qualquer preocupação do sujeito astuto em fazer-se um grande revolucionário, o que lhe importa, acima de tudo, é acomodar, ao inserir-se em redes de negócios e intercâmbios, lo suyo (a sua situação) e daqueles que lhe são próximos, incluindo, numa visão distanciada e variando o ponto de referência, o próprio batey. Em termos nativos, esses últimos sujeitos são denominados escapados. O Estado propalou a eficiência, mas as pessoas, entre ruínas, desdobraram-na em astúcia. Neste artigo, não me atenho a tal tema, frisei-o apenas porque é necessário ter ciência dele para ler as reconstituições particulares dos detritos do Estado.

\section{SUCATAS DO ESTADO EM CASAS PARTICULARES: RECONSTRUÇÕES}

Conquanto cansativas, as viagens demoradas entre batejes me permitiram pôr em prática o exercício da escuta e da observação. Em variados meios de transporte, ouvia conversas alheias, inspecionava o que os passageiros compravam no centro da cidade na tentativa de verificar o que poderia estar em falta nos mercados locais, interagia com as pessoas mais simpáticas e vislumbrava, à distância, as estradas que antecediam os bateyes. Fazendo tramos, notei uma característica comum às zonas com centrais desestruturados: o emprego de ferro e zinco nas casas. Quando o emprego desses itens aumentava, não tinha dúvida de que havia usinas pelas redondezas. As chaminés apenas ratificavam a percepção. Nos bateyes, por seu turno, a quantidade de ferro se ampliava ainda mais, sendo difícil identificar uma moradia sem esse material aplicado em alguma de suas partes. Ao lado das carroças e das calças e camisas marrons de tecido grosso, normalmente usadas por trabalhadores do campo e operários, 
os metais, oxidados ou pintados, compunham uma espécie de paisagem do açúcar.

A proveniência da ferragem era fácil de ser determinada. Tratava-se de equipamentos inutilizados, caldeiras, tambores, malhas de aço e diferentes tipos de chatarra (sucata) das estruturas desmanteladas. Cercas, caixas d'água, armações de garagem e de teto, portões, galinheiros, bancos, tanques, todas essas construções surgiam como uma estratégia de reaproveitamento do que, à primeira vista, poderia não servir mais para nada. Demolia-se, de um lado, reconstruía-se, de outro: trechos das linhas de trem desfaziam-se, por conseguinte, brotavam chiqueiros, muros; decompunha-se o teto do edifício do açúcar, criavam-se garagens; e assim por diante. Dessa maneira, em vez de desaparecer, os centrais deixavam seus rastros em um espaço que se alongava para além dos escombros que limitavam o desgastado piso de azúcar (o setor de produção).

Ao ver criativas arquiteturas, questionava-me acerca dos modos de aquisição da matéria-prima que as formava. Como me explicavam, os centrais eram estatais, logo, o que se mantinha dentro deles também pertencia ao Estado, até mesmo as chatarras. Alguns ainda indicavam que não se permitia entrar e sair com o que se quisesse dos locais em que uns poucos funcionários cumpriam a tarefa do desmantelamento. Existia uma vigilância, um controle. Verifiquei isso em um batey, onde, na portaria do antigo central, havia uma corda velha fazendo as vezes de portão e, numa parede carcomida, a indicação de que

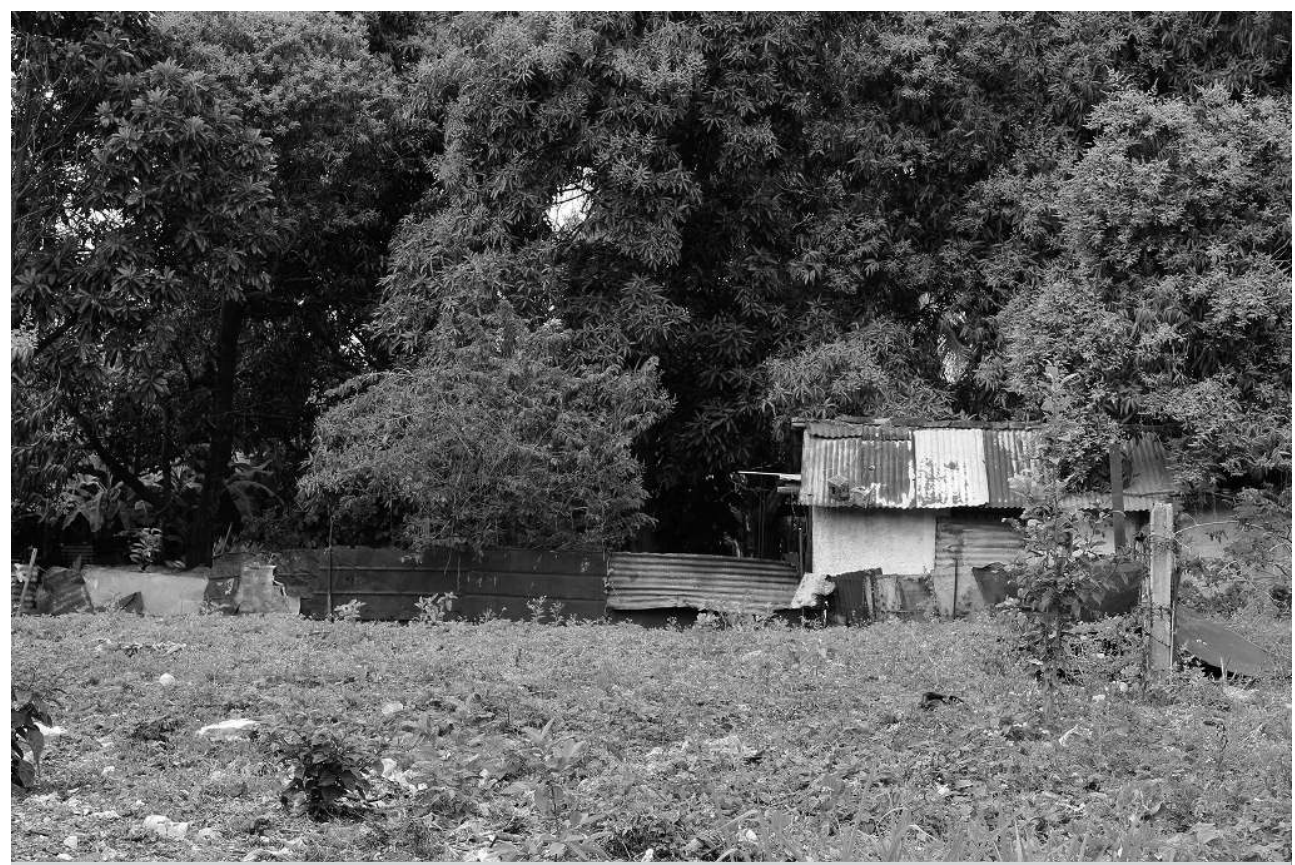

Figura 5 - A mobilidade das sucatas. Fonte: Arquivos do autor (Matanzas, Cuba, 2016). 
estranhos não podiam passar. Uma vigilante fazia a ronda. Abordei-a. Relatou-me que fora "realocada" de profissão, mas que seu posto era provisório, só trabalharia ali até a retirada das peças. As que estavam em melhor estado de uso e eram úteis e caras, como motores, já tinham sido enviadas, supostamente, para indústrias ainda em funcionamento. Faltavam, porém, grupos de matérias-primas que não podiam ser desperdiçadas. Cooperativas da região costumavam comprá-las. Perguntei-lhe se não havia desaparecimentos indevidos de pedaços de maquinários. Com firmeza, disse-me que mantinha uma lista de tudo o que saía. Como era um estrangeiro que aparecera de repente para lhe fazer inquirições que envolviam uma temática complicada, as quais, apesar de não ser o meu objetivo, punham em xeque sua própria atuação, ela jamais confirmaria qualquer incidência de ilegalidades em torno das sucatas. Horas antes, minha acompanhante - uma conhecida que me guiava pelo bairro, destaco - fugira da mesma questão, fingindo não entender o meu ponto. Suspeito que ela evitou maiores detalhes sobre o que eu chamava de roubo porque ocupava um cargo importante numa instituição estatal e era vinculada ao partido (designação dada o partido comunista cubano) - não podia, nesse sentido, afirmar nada que difamasse o batey para um estrangeiro; preferia manter um discurso convencional em que sobressaíam apenas qualidades positivas da área e seus habitantes. Não faltavam histórias de estrangeiros que deturpavam a imagem do país no exterior e de cubanos que arranjavam problemas com o Estado por falar demais; assim sendo, mesmo que ressaltasse que não intencionava causar nenhum desconforto nem prejudicar ninguém, muitas pessoas, sempre desconfiadas, preferiam escapar de complicações futuras.

Com discurso menos formatado, o pai da segunda senhora não hesitou em apontar que todo mundo do batey tinha alguma chatarra obtida por la izquierda. Por esse motivo, ninguém podia julgar ninguém, cada um se "arranjava a seu modo". Ele mesmo afirmava ter um tanque de água construído com materiais do desmantelamento, e não tivera dificuldade para consegui-lo sem a necessidade de investimentos em pesos, pois, como fora trabalhador açucareiro desde sua juventude, conhecia a maioria dos funcionários da empresa. Disse também que os vigilantes ocupavam uma posição fundamental no processo de retirada de sucatas, havendo aqueles que, para fazer algum dinheiro a mais, "ajudavam" os moradores. Sua filha, sentada conosco na sala de estar, sorria, sem demonstrar qualquer discordância em relação a seus pareceres e explicações.

Enquanto uns não se adentravam nos aspectos morais da apropriação de sucatas, outros os destacavam em seus comentários. Julián, por exemplo, ligava o encerramento das atividades açucareiras à ganância desmesurada de muitos moradores, que, em lugar de proteger o edifício que fora atingido e desfigurado pelo furacão Michelle, preferiram "rompê-lo" mais e mais, trasladando para suas casas "aquilo que não lhes pertencia": "[...] Assim se via. [...] Um carregou um parafuso, outro levou um tubo". No fim, conforme sua narra- 
tiva, por causa da "avareza", tudo foi desbaratado, sem nenhuma possibilidade de reerguer-se: "Esse era o enfriadero. Não vê como o desbarataram? É o que lhe digo: o ser humano é muito ruim". As ideias de Julián dialogavam com as do machetero (cortador de cana) Reynaldo Castro, famoso pelos altos índices de eficiência, tendo recebido menções na revista Bohemia, estímulos do Estado (como carros e geladeiras) e diplomas (certificados oferecidos pelas empresas socialistas aos trabalhadores que se destacavam). ${ }^{26}$ Para ele, os inaceitáveis "desaparecimentos" e "destruições" de equipamentos e demais estruturas que faziam parte do mundo dos centrais foram "barbaridades que se toleraram": "Aqui tem gente que fez dinheiro vendendo sucata. Quem tem sucata nesse país? O Estado. Certas pessoas pareciam urubus em cima de animal morto, cortando ferros com oxigênio e acetileno. E o oxigênio e o acetileno de quem é? Também do Estado". Em seus termos, tal aceitação conduziu a economia açucareira a um "caminho [...] intransitável” (Rodríguez 2013: 105-109).

Mais do que as moralidades em torno dos usos das sucatas, o que quero sublinhar é o processo des-construtivo do que sai do central e passa a compor o espaço familiar, descentralizando ou particularizando os bens que antes foram do Estado. Se até agora citei apenas materiais como ferragens, canos, tambores e telhas de zinco, como última ilustração, destaco a autofabricação de tratores. Conforme me relataram, muitos dos tratores que circulavam pelos bateyes provinham da soldagem de peças de outros equipamentos do central, a maior parte espalhada pelas casas, como motores, portas de aço, pneus, escapamentos, volantes, basculantes. Para acessá-los, conhecer os trechos que levavam até eles era uma das exigências, e, para tanto, havia de se imiscuir nos negócios da informalidade e constituir redes confiáveis de "parceiros". A descrição desse percurso de junções de pedaços de sucatas (ou não) foi-me oferecida por um campesino:

"Esse trator foi montado de pedaço em pedaço [apontou para o veículo]. As peças foram 'buscadas' e 'ajuntadas'. [...] É feito com peças de outros tratores. Todos esses tratores são feitos a partir de peças 'buscadas', os motores 'buscados' aqui e acolá, e assim ele vai sendo montado, até que fica completo. [...] Eu chamei um mecânico, o paguei, e ele o montou. [...] Não comprei as peças pelo Estado [ou seja, não fez uso do mercado legal estatal]. [Como alguém sabe que estão vendendo algo?] Ah, para isso, é preciso conhecer todos o pontos-chave que se dedicam a isso. Ele lhe dá uma peça, e você diz: 'Eu vou para aquele lado agora, então'. E se vai para aquele ponto e não encontra nada, ele diz: 'Vá a esse outro lugar. E se não achar nada, dirija para aquele outro, porque aí sim deve haver alguma coisa para você' ".

26 Rodríguez (2013) traz um longo testemunho de Reynaldo Castro. Entrevistei esse personagem em 2015. Entretanto, preferi utilizar aqui o material publicado previamente pela jornalista cubana. 
Lendo a passagem, diria que as coisas des-feitas recontam uma história, mas, ahora, de um ponto de vista subjetivo, a partir do qual cada elemento carrega, ele também, a história de como foi arranjado e rearranjado ao redor de outros.

\section{PROBLEMATIZANDO A RUÍNA}

Num bate-papo diante de uma usina desmantelada, um senhor foi firme em sua conclusão: os ferros espalhados ao redor da antiga chaminé, embora fossem considerados sucatas, não eram, para ele, uma ruína. "As ruínas já não servem para nada. Mas [a] isso aí ainda pode ser dado uso", concluía. Não havia como discordar de sua percepção. As casas sinalizavam o que ele expressava com clareza. Muitas construções recompunham, ao menos fisicamente, o central derrubado, prolongando sua extensão no tempo e alongando as afetividades: olhar para um tanque de ferro com água guardada para limpar chiqueiros e para as próprias cercas que os formavam, vez ou outra, era um motivo para lembrar de uma usina que se foi; os tetos de zinco emitiam memórias dos desfazimentos do ciclone Michelle; uma escumadeira se ligava às malhas de aço descartadas ou vendidas por funcionários; as paredes de uma casa se levantavam porque vigas de ferro "buscadas" as sustentavam; massa de tomate ou óleos de sementes eram consumidos pelo fato de que alguém inventou uma máquina moedora com peças negociadas por la izquierda; pregos de cercas eram produzidos por terceiros porque foram dadas funções a ferros maleáveis encontrados pelos caminhos dos terrenos de cana; e a lista continuaria. Percebe-se, portanto, que as pessoas não se perdiam na nostalgia ou melancolia, como se estivessem de todo arruinadas. Isso não acontecia porque elas engendravam novidades a partir de detritos, daí uma sucata ser sinal de refazimento.

As ruínas, eu tentaria ver assim, não estavam substantivadas como algo inerte, impossível de se mover, como um intocável bem patrimonializado ou objeto museológico. Edensor (2005: 21, 24) sugere que "espaços arruinados permitem uma ampla variedade de práticas", muitas delas transgressoras das normatividades, a partir das quais são encontrados "novos usos para velhos pedaços de maquinários". Ele também define: "ruínas não têm forma única, são múltiplas" (Edensor 2005: 4). Os usos aqui apresentados jogam exatamente com a multiplicidade dos espaços arruinados.

Na mesma linha, Stoler (2013) e Collins (2013) demonstram que, menos que representações fixas de uma história passada, as ruínas, para que alcancem produtividade analítica, devem ser compreendidas como elementos em atividade que geram efeitos nas paisagens, nas sensibilidades e nos corpos dos sujeitos que por elas são afetados. O caso dos centrais desativados é um exemplo interessante de como os habitantes dos bateyes sabem, com versatilidade e astúcia, lidar com aquilo que os toca, recorda incessantemente e enferruja a 


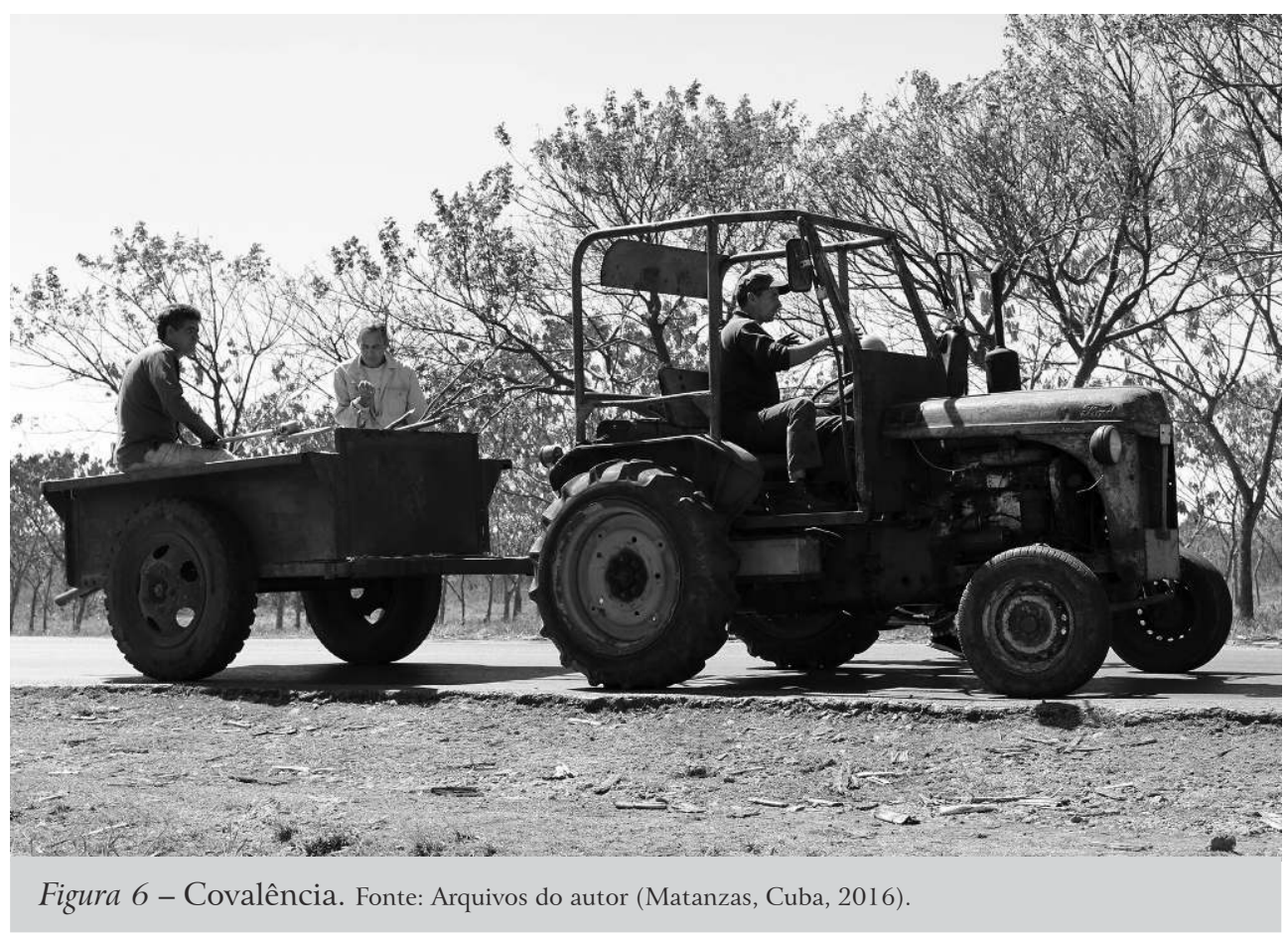

paisagem. Muitos deles, como salientam, impossibilitados de abandonar suas casas em busca de lugares com mais movimento, não conseguem proteger-se de toda a ferragem que prolifera. Sem saída, são obrigados a habitá-las, ressignificá-las, transformá-las de acordo com aquilo que têm disponível como instrumentos de ação e criação.

O desmantelamento parece ser a revelação de um tesouro a ser carregado, explorado, remontado, redefinido, reposto (Del Real e Pertierra 2008; Pertierra 2010; Schwenkel 2012, 2013; Navaro-Yashin 2007). Desmantelar, sugeriria, não é desfazer. É des-manter, des-cuidar, des-montar, des-fazer. A arquitetura dos centrais, quando removida de seus pontos e ajuntada em outros para conformar estruturas nem sempre esperadas, aparece como objetos móveis que solucionam necessidades do fazer cotidiano e reconstituem a vida; uma arquitetura que se relaciona com materiais vários para arranjar vias de escapar de ao menos parte de um grupo de carências, do qual os objetos e as casas participam. Uma redistribuição de peças que, na criatividade, mas não sem desgaste, repõe parcela do que falta. ${ }^{27}$

27 Sobre ruínas, infraestrutura arquitetônica e novas socialidades no socialismo vietnamita, ver Cristina Schwenkel (2012). A autora desdobra as redes de solidariedade para compreender o que designa como "ética do cuidado e da reparação". 


\section{CONCLUSÃO: SILÊNCIOS}

As descrições e análises etnográficas amarradas neste artigo tomaram como elemento principal as recordações (i)materiais de moradores de bateyes afetados pela reestruturação desmantelada do campo açucareiro. A partir delas, apresentei uma paisagem esquecida pelos estudos antropológicos contemporâneos sobre Cuba, normalmente interessados em questões como religião, raça, gênero, turismo, transição econômica, dolarização e sociedade civil nos grandes centros urbanos (Fernandes 2004, 2010; Hearn 2008; Hernandez-Reguant 2009; Holbraad 2002; Roland 2010; Ryer 2006). É indubitável a amplitude e a relevância dessas pesquisas para uma cartografia das novas configurações sociais de Cuba, das "versões [nativas] de socialismo" (Rosendahl 1997) e também das compatibilidades e dos antagonismos com o capitalismo globalizado. Não obstante, a diversidade temática não tem como correspondente direto uma variedade de lugares etnografados - os trabalhos circunscrevem-se às capitais, sobretudo Havana, convertida em metonímia da ilha. Outras zonas - e discussões que poderiam advir do estudo delas - são relegadas ao segundo plano ou, no pior dos casos, apagadas.

O açúcar como objeto de debate antropológico profícuo talvez seja uma das ausências mais notórias. Mesmo no campo historiográfico, em que há uma grande produção sobre o tema, são raras as propostas que ousam enveredar-se para o pós-1959; quando o fazem, destacam apenas um retrato estatístico-conjuntural generalizante, como Zanetti (2012). A verdade é que, sem importar as vinculações científicas, a vida pública e privada e as resistências nos bateyes açucareiros atuais permanecem inexploradas, seguem como uma incógnita. ${ }^{28}$

Há pouco mais de 50 anos, John DuMoulin (1966) realizou um levantamento quantitativo para avaliar a reconfiguração social nos bateyes com o aparecimento do "operariado revolucionário". Ele demonstrou como o setor açucareiro estatizado passou a tomar conta da vida local, alterando drasticamente a organização laboral. Afirmava DuMoulin (1966: 33): "[No 'tempo morto'] o trabalho no campo [...] era o meio de vida tanto dos operários que viviam no campo quanto dos que tinham residência urbana, hoje significa pouco para estes últimos". Inspirado em sua investigação, tentei romper parcela do silêncio acadêmico que produz certo desaparecimento dos sujeitos que estão em convivialidade (Gilroy 2006: 40), "fazendo a vida" nos bateyes, ou seja, criando modos de produzir a existência em zonas de difícil acesso a mercadorias e dinheiro, com hierarquizações espaciais, desigualdades socioeconômicas e conflitos diversificados. 
O mencionado "silêncio acadêmico" pode ser interpretado segundo ao menos dois motivos principais: (i) o interesse dos pesquisadores se voltou, até então, pelas formas de reconfiguração do socialismo cubano, com o florescimento de questões etnográficas que dialogavam com temas candentes e já estabelecidos nos campos antropológicos e políticos, como os casos dos estudos de religião afro-cubana e dos coletivos e associações próximos ao debate sobre sociedade civil, sendo esta estabelecida segundo os moldes propriamente cubanos, para os quais os modelos da teoria liberal são insuficientes ou impróprios (Fernandes 2004; Zurbano 2009); (ii) a dificuldade de realizar investigações em áreas distantes dos grandes centros urbanos, nas quais inexistem casas com licença para aluguel a estrangeiros, algo que impede a permanência e circulação de pesquisadores, a não ser que sejam operadas negociações extraoficiais. Junto disso, encontram-se, também, as complicações com o Estado e sua "intolerância política” (Rosendahl 1997: 26). Esses elementos, de acordo com Ryer (2006: 29), geraram nos antropólogos um sentimento paranoico de constante controle e conspiração, o que, parece-me, fez com que se criasse um afastamento deles do mundo rural, comumente conhecido como lugar onde ainda impera o socialismo. As complicadas e emblemáticas experiências de Martinez-Alier (1974: vi-ix), Oscar Lewis (Lewis, Lewis e Rigdon 1977: ix) e Rosendahl (1997: 26), que lidaram com acusações de espionagem, anticomunismo e contrarrevolução, comprovam a conclusão de Ryer (2006). Seguramente, já na segunda década dos anos 2000, a situação de pesquisa se alterou e os olhares controladores e acusadores não são os mesmos nem possuem tamanha efetividade. De toda maneira, seus detritos - para continuar na linguagem das ruínas ainda emanam afetos negativos de vigilância, e isso talvez ainda mantenha os estudiosos, com seus gravadores, cadernetas e máquinas fotográficas, na retaguarda, ou melhor, na aparente invisibilidade possibilitada pelas capitais turísticas cubanas.

Se, por um lado, não posso deixar de apontar que existe um mutismo sobre o tema das atuais comunidades açucareiras em Cuba - seja qual for o motivo -, por outro, sublinho que o realce dado à força do açúcar nas trajetórias sociais e históricas do país não é algo novo. Poderia até ser afirmado que apenas revisito conclusões de outros estudiosos. Nesse grupo, estaria, é claro, Don Fernando Ortiz e seu Contrapunteo Cubano del Tabaco y el Azúcar (1963 [1940]: 3), o qual assegura, na introdução, que "estudar a história de Cuba é, fundamentalmente, estudar a história do açúcar e do tabaco como sistemas viscerais de sua economia". Um detalhe que diferencia minha perspectiva daquela do famoso pesquisador cubano é exatamente o fato de que lido com uma ausência presentificada em rastros (i)materiais viscerais. Vejo, respaldado nas narrativas dos meus interlocutores, o mundo do açúcar naquilo que ele deixou de ser, em sua intensa transformação em uma sucata enferrujada e, posteriormente, requalificada em uma nova estrutura pelo artifício do des-montar. Não é propriamente 
o açúcar como uma espécie de constituidor de cultura que me interessa, mas o que as pessoas fazem nos momentos em que sua efetiva presença só é alcançada a partir de partículas ou espectros de um antes que ainda circula pelo ahora, afetando-o.

Ir ao encontro desse transmutável mundo açucareiro possibilitou-me fugir de uma explicação genérica e macroscópica da precariedade da economia a partir apenas de elementos históricos e estatísticos do período especial. Nesse exercício, busquei inspiração e apoio analítico nas contribuições da antropologia sobre Cuba que se afastam de qualquer argumentação que abra brechas para construir esse "período" como uma resposta prévia, familiar e abarcadora para diferentes fraturas e feituras sociais (por exemplo, Brotherton 2012; Del Real e Pertierra 2008; Pertierra 2010; Holbraad 2010; Stout 2014). Juntos - e entre eles também se insere a minha abordagem -, tais trabalhos demonstram que na paisagem pós-soviética cubana o período especial atua como um actante (Latour 2008) no meio de muitos outros, não menos relevantes e potentes para pensar as conformações do social. Assim, considerei os desmantelamentos como algo a ser descortinado nas particularidades de seus resíduos, manuseando, para tanto, as apreensões e percepções das pessoas e das reorganizações dos objetos. Meu interesse foi, enfim, indicar como a transformação açucareira pertencia, na acepção de Strathern (2014: 137), aos moradores dos bateyes e, dentro disso, como conjugavam suas experiências espaço-temporais cheias de lembranças, deslocamentos, conflitos, tramas, dúvidas e esperas, sendo a principal delas o fim da "silenciosa moenda": o retorno da vida no batey, ainda que uma vida feita do engenho de sucatas, em um mundo em que prevalece a premência do movimento e da invenção. iAquî no se puede parar!

\section{BIBLIOGRAFIA}

Brotherton, Sean, 2012, Revolutionary Medicine: Health and the Body in Post-Soviet Cuba. Durham, Duke University Press.

CANTERO, Justo Germán, 2005, Los Ingenios: Colección de Vistas de los Principales Ingenios de Azúcar de la Isla de Cuba, vol. 1. Madrid, Editorial CSIC-CSIC Press.

CASTrO, Carlos Gomes, 2014, Demarcadores e Objetos em Campanha: a Comissão Brasileira Demarcadora de Limites e a Fabricação de Fronteiras. São Paulo, Cultura Acadêmica.

CASTRO, Carlos Gomes, 2017, Hacer la Vida: Inventos, Negócios e Trampas em um Batey Cubano. Rio de Janeiro, Museu Nacional, Universidade Federal do Rio de Janeiro, tese de doutorado. 
COLLINS, John, 2013, "Ruins, redemption, and Brazil's imperial exception”, em Ann Laura Stoler (org.), Imperial Debris: on Ruins and Ruination. Durham e Londres, Duke University Press, 162-193.

CUNHA, Olívia, 2010, "Estática milagrosa: uma introdução aos espaços-tempo em transformação em Cuba”, em Olívia Cunha (org.), Outras Ilhas: Espaços, Temporalidades e Transformações em Cuba. Rio de Janeiro, Aeroplano, 9-33.

DEL REAL, Patricio, e Cristina PERTIERRA, 2008, "Inventar: recent struggles and inventions in housing in two Cuban cities". Buildings \& Landscapes: Journal of the Vernacular Architecture Forum, 15: 78-92.

DUMOULIN, John, 1966, "Procedencia social de los obreros de un ingenio azucarero", Etnología y Folklore, Academia de Ciencias de Cuba, 2: 27-48.

EDENSOR, Tim, 2005, Industrial Ruins: Spaces, Aesthetics and Materiality. Oxford e Nova Iorque, Berg.

ESTRADA, Ana Vera, 2012, Guajiros del Siglo XXI. Havana, Instituto Cubano de Investigación Cultural Juan Marinello.

FERNANDES, Sujatha, 2004, "Critical perspectives on civil society", em Maurice A. Font (org.), Cuba Today: Continuity and Change since the "Período Especial". Nova Iorque, Bildner Center for Western Hemisphere Studies, 3-12.

FERNANDES, Sujatha, 2010, "Feito em Havana: rap, espaço e política racial”, em Olívia Cunha, Outras Ilhas: Espaços, Temporalidades e Transformações em Cuba. Rio de Janeiro, Aeroplano, 425-446.

FREDERIK, Laurie A., 2012, Trumpets in the Mountain: Theater and the Politcs of National Culture in Cuba. Durham, Duke University Press.

GILROY, Paul, 2006, "Multiculture in times of war: an inaugural lecture given at London School of Economics”, Critical Quarterly, 48 (4): 27-45.

GORDY, Katherine, 2004, "Dollarization, consumer capitalism and popular responses”, em Maurice A. Font (org.), Cuba Today: Continuity and Change since the "Período Especial". Nova Iorque, Bildner Center for Western Hemisphere Studies, 13-30.

HEARN, Adrian, 2008. Cuba: Religion, Social Capital, and Development, Durham e Londres, Duke University Press.

HERNANDEZ-REGUANT, Ariana, 2009, "Writing the special period: an introduction", em Ariana Hernandez-Reguant (org.), Cuba in the Special Period: Culture and Ideology in 1990s. Nova Iorque, Palgrave Macmillan, 1-20.

HOLBRAAD, Martin, 2002, Belief in Necessity: Ifá Divination and Money in Contemporary Havana. Cambridge, King's College, University of Cambridge, tese de doutorado.

HOLBRAAD, Martin, 2010, "Dinheiro e necessidade no Período Especial de Havana", em Olívia Cunha (org.), Outras Ilhas: Espaços, Temporalidades e Transformações em Cuba. Rio de Janeiro, Aeroplano, 367-393.

LATOUR, Bruno, 2008, Reensamblar lo Social: Una Introducción a la Teoría del Actor-Red. Buenos Aires, Manantial.

LEWIS, Oscar, Ruth M. LEWIS, e Susan M. RIGDON., 1977, Four Men Living the Revolution: An Oral History of Contemporary Cuba. Urbana, University of Illinois Press.

MANDEL, Ruth, e Caroline HUMPHREY, 2002, Markets and Moralities: Ethnographies of Postsocialism. Oxford e Nova Iorque, Berg.

MARTINEZ-ALIER, Verena, 1974, Marriage, Class and Colour in Nineteenth Century Cuba. Ann Arbor, University of Michigan Press. 
NAVARO-YASHIN, Yael, 2007, "Affective spaces, melancholic objects: ruination and production of anthropological knowledge", Journal of the Royal Anthropological Institute (n.s.), 15: 1-18.

NAVARO-YASHIN, Yael, 2012, The Make-Believe Space: Affective Geography in a Postwar Polity. Durham e Londres, Duke University Press.

ORTIZ, Fernando, 1963 [1940], Contrapunteo Cubano del Tabaco y el Azúcar. Havana, Consejo Nacional de Cultura.

PERTIERRA, Cristina, 2010, "Materialidade da escassez: as residências urbanas de Cuba e sua cultura material”, em Olívia Cunha (org.), Outras Ilhas: Espaços, Temporalidades e Transformações em Cuba. Rio de Janeiro, Aeroplano, 395-423.

PERTIERRA, Cristina, 201 1, Cuba: The Struggle for Comsumption. Coconut Creek, Caribbean Studies Press.

RODRÍGUEZ, Maylan A., 2013, La Callada Molienda. Havana, Ediciones La Memoria.

ROLAND, L. Kaifa, 2010, Cuban Color in Tourism and La Lucha: An Ethnography of Racial Meanings. Nova Iorque, Oxford University Press.

ROSENDAHL, Mona, 1997, Inside the Revolution: Everyday Life in Socialist Cuba. Nova Iorque,

Cornell University Press.

RYER, Paul, 2006, Between La Yuma and Africa: Locating the Color of Contemporary Cuba. University of Chicago, Department of Anthropology, tese de doutorado.

SCHWENKEL, Christina, 2012, "Civilizing the city: socialist ruins and urban renewal in Central Vietnam”, Positions, 20 (2): 436-471.

SCHWENKEL, Christina, 2013, "Post/socialist affect: ruination and reconstruction of the nation in urban Vietnam", Cultural Anthropology, 28 (2): 252-277.

SIMONI, Valerio, 2015, "Intimacy and belonging in Cuban tourism and migration", The Cambridge Journal of Anthropology, 33 (2): 26-41.

STOLER, Ann L., 2013, “The rot remains: from ruin to ruination”, em Ann Laura Stoler (org.), Imperial Debris: on Ruins and Ruination. Durham e Londres, Duke University Press, $1-35$.

STOUT, Noelle, 2014, After Love: Queer Intimacy and Erotic Economies in Post-Soviet Cuba. Durham e Londres, Duke University Press.

STRATHERN, Marilyn, 2014, "Os limites da autoantropologia", em Marilyn Strathern, O Efeito Etnográfico. São Paulo, Cosac Naify, 133-157.

ZANETTI, Oscar, 2012, Esplendor y Decadencia del Azúcar en las Antillas Hispanas. Havana, Editorial Ciencias Sociales.

ZURBANO, Roberto, 2009, “El rap cubano: can't stop, won't stop the movement!”, em Arina Hernandez-Reguant (org.), Cuba in the Special Period: Culture and Ideology in 1990s. Nova Iorque, Palgrave Macmillan, 143-158. 